\title{
GRUPY ORGANIZUJĄCE ZWIEDZANIE MIASTA, ICH MOTYWY I ROLE JAKO POPULARYZATORÓW TURYSTYKI I REKREACJI - PRZYKŁAD ŁODZI
}

\section{Wprowadzenie}

Turystyka i rekreacja to zjawiska bardzo dynamicznie rozwijające się we współczesnym świecie. Jest wiele czynników wpływających na intensyfikację tych dziedzin ludzkiego życia. Z całą pewnością przyczyn związanych ze wzrostem zainteresowania turystyką i rekreacją należy upatrywać w postępie technologicznym, wyższych dochodach ludności, wzroście wymiaru czasu wolnego przeznaczanego na różnorodne zajęcia wolnoczasowe oraz większej ruchliwości społeczeństw. Dodatkowo ludzie coraz częściej w podejmowaniu decyzji turystycznych i rekreacyjnych kierują się swoimi indywidualnymi preferencjami, ponieważ takie wykorzystanie czasu wolnego zaczyna funkcjonować w świadomości ludzkiej jako wskaźnik jakości życia. Współcześnie społeczeństwa nadają turystyce i rekreacji bardzo ważne role, są to m.in. możliwość aktywnego wypoczynku, relaksu, regeneracji sił fizycznych i psychicznych, a co za tym idzie poprawy ogólnego stanu zdrowia (LUBOWIECKI-VIKUK 2008).

Aby móc uprawiać turystykę i rekreację ludzie wykorzystują wszelkie nadające się do tego obszary, wśród nich tereny naturalne oraz miejsca zorganizowane przez człowieka specjalnie do tych celów. To właśnie miasta 
jako całości, obok m.in. przestrzeni postmilitarnych, zalicza się do nowych obszarów turystyczno-rekreacyjnych (LISZEWSKI 2006). Miasta to tereny bogate w różnorodne atrakcje, które przyciągają turystów. Wśród tych walorów należy wymienić dziedzictwo kulturowe miejsca, centra handlowe czy tereny zielone.

Turystyka zajmuje szczególne miejsce w miastach, które do tej pory pełniły funkcję ośrodków przemysłowych, gdzie była dotychczas zjawiskiem marginalnym. Współcześnie wiele takich miast jest poddawanych rewitalizacji. W rezultacie takich działań zyskują one nowe zagospodarowanie czy nowe atrakcje, które mogą przyczynić się do wzrostu liczby turystów i osób odwiedzających te miejscowości (WYZUJ 2008).

Celem niniejszej pracy jest przeprowadzenie analizy sposobu organizacji turystyki i rekreacji w mieście poprzemysłowym, jakim jest Łódź, które dysponuje dużym potencjałem turystycznym. Ocenie zostało poddanych 14 instytucji, wśród których siedem jest proponowanych jako przewodnicy po Łodzi na stronie internetowej www.turystyczna.lodz.pl. Informacje o pozostałych podmiotach można znaleźć w serwisie społecznościowym Facebook. W analizie wzięto pod uwage m.in. następujące elementy działalności placówek: typ instytucji, główne cele ich aktywności, formy promocji, średni dystans i czas zwiedzania. Sprawdzono, czy instytucje powtarzają proponowane miejsca i trasy. Analizę przygotowano w oparciu o materiały źródłowe dostępne na stronach internetowych tych organizacji oraz wywiady przeprowadzone z osobami zaangażowanymi w tę działalność.

\section{2. Łódź jako miejsce promowane przez organizatorów turystyki i rekreacji}

Duże miasto mając odpowiedni potencjał może być traktowane jako miejsce recepcji turystycznej, główny cel podróży turystycznej. W takim przypadku możemy mówić o zjawisku nazywanym "turystyką miejską" (MATCZAK 2008). Turystykę miejską można rozumieć jako aktywność turystyczną podejmowaną przez turystów na terenie wyposażonym we właściwą infrastrukturę turystyczną, a także grupy zabytków kultury czy architektury, które mogą stanowić impuls dla turystów do przyjazdu do konkretnego miasta (Voultsaki 2000, cyt. za: PAWLICZ 2008). 
Łódź jest centrum krajoznawczym i głównym ośrodkiem regionu łódzkiego. Jest trzecim co do wielkości miastem w Polsce, liczącym 661,9 tys. mieszkańców (http://lodz.naszemiasto.pl). To znany były ośrodek przemysłu lekkiego, włókienniczego, ale również miasto akademickie i prężnie działający ośrodek naukowy (KRUCZEK, SACHA 2001).

Termin „centrum krajoznawcze” odnosi się do dużego miasta, które samo w sobie jest przedmiotem zainteresowania turystów z powodu licznych walorów krajoznawczych, usług handlowych i rozrywkowych. Łódź można zaliczyć do grupy rozwijających turystykę ośrodków wielkomiejskich o różnorodnych walorach miejsca (KRUCZEK, SACHA 2001). Jest miastem bogatym $\mathrm{w}$ walory $\mathrm{i}$ atrakcje, takie jak m.in. zabytki architektury przemysłowej z XIX wieku, muzea i inne obiekty kultury czy wiele imprez rozrywkowych oraz sportowych, często o międzynarodowej randze. Ruch turystyczny przeważnie koncentruje się $\mathrm{w}$ centrum, na terenach silnie zurbanizowanych, którym towarzyszy zagospodarowanie turystyczne i paraturystyczne.

Potencjał Łodzi niewątpliwie związany jest $\mathrm{z}$ dwoma elementami, pierwszy łączy się z tradycjami XIX-wiecznego miasta przemysłowego powstałego na „surowym korzeniu”, a drugi z wielokulturowością i czterema głównymi narodami (Polacy, Niemcy, Żydzi i Rosjanie), które zamieszkiwały kiedyś Łódź i wpłynęły na krajobraz miasta.

Na początku XX wieku Łódź była miastem tolerancji, w którym obok siebie żyły różne narody z własnymi religiami i kulturami. W wyniku II rozbioru Polski w 1796 roku Łódź znalazła się w zaborze pruskim, a w 1807 roku w Księstwie Warszawskim. W rezultacie Kongresu Wiedeńskiego w roku 1815 została włączona do zaboru rosyjskiego i znalazła się w Królestwie Polskim lub, inaczej - w Królestwie Kongresowym. Napływ osadników niemieckich (rozpoczęty w latach 20. XIX w.) związany był z decyzją dotyczącą uprzemysłowienia miasteczek rządowych (Łódź była miastem rządowym od 1796 r.) (WOJALSKI 2000, s. 9) i założenia osad fabrycznych. Do osiedlenia się w Łodzi zachęcano ludzi wykazujących się umiejętnościami tkania, przędzenia i farbowania tkanin lnianych i wełnianych. Osadnicy migrujący spoza zaboru rosyjskiego mogli liczyć na pomoc materialną, m.in. otrzymanie ziemi i drewna pod budowę domów i warsztatów. Z tego powodu Łódź zaczęła rozwijać się jako centrum przemysłu tkackiego i sukienniczego. Rozkwit Łodzi przemysłowej przyciągał również osadników żydowskich, dla których w 1825 roku wytyczono dzielnicę na dzisiejszym Starym Mieście. Napływający imigranci rosyjscy byli przede wszystkim urzędnikami wyznaczonymi do pracy $w$ Łodzi wraz $\mathrm{z}$ rodzinami. O koegzystencji tych narodów mówią 
dane pochodzące ze spisu mieszkańców z tego okresu. W końcu XIX wieku (1864) populacja Łodzi wynosiła 38 100, wśród nich Polacy stanowili ponad $38 \%$ ludności, Niemcy 41,5\%, Żydzi ponad 19\%, a Rosjanie 0,2\% (WOJALSKI 2000 , s. 24). Łódź jako miasto wielonarodowe i wielokulturowe istniało do wybuchu II wojny światowej.

\section{Charakterystyka działalności badanych instytucji Łodzi}

W Łodzi funkcjonuje 14 placówek odpowiedzialnych za organizację turystyki, które swoimi działaniami promują miasto i region (tab. 1). Część z tych instytucji, jako stowarzyszenia lub fundacje, prowadzi niekomercyjną działalność. Pozostałe są nastawione na zysk, prowadzą działalność komercyjną. Wszystkie 14 podmiotów zajmują się rozwojem turystyki i rekreacji na płaszczyźnie lokalnej. Rozwój lokalny jest najczęściej traktowany jako proces wykorzystujący zasoby przyrodnicze i potencjał społeczno-gospodarczy danego terenu. Lokalny rozwój turystyki jest często utożsamiany z funkcjonowaniem obszarów recepcji turystycznej, które mogą ograniczać się do konkretnych miejscowości lub wykraczać poza nie i obejmować większe tereny (MIKA 2014).

Instytucje organizujące zwiedzanie Łodzi różnią się między sobą wieloma cechami (tab. 2). Tylko na stronach internetowych siedmiu podmiotów można odnaleźć informację o dacie założenia firmy. Wśród tych organizacji trzy zostały powołane przed rokiem 1997, a cztery po 2001. Przykładowo, sześć z 14 organizacji grup prowadzi działalność niekomercyjną, czyli utrzymuje się z innych źródeł niż opłaty pobierane od uczestników (dotacje zewnętrzne, składki członkowskie itp.), siedem z 14 grup, czyli połowa, to organizacje komercyjne nastawione na zysk, który pochodzi od uczestników wycieczek, tj. turystów. Tylko jeden podmiot informuje o prowadzeniu działań niekomercyjnych i komercyjnych, łączy oba typy funkcjonowania (Przewodnicy Łódzcy Totu-Totam). Pisząc o głównych celach, przyświecających badanym instytucjom, wszystkie podmioty komunikują na stronach internetowych o edukowaniu społeczeństwa, o potrzebie poznania Łodzi jako niezwykłego miasta. O aktywnym wypoczynku i regeneracji sił poprzez turystykę i rekreację informuje pięć z 14 grup. Dodatkowo podmioty prowadzące działalność komercyjną za jeden z głównych celów stawiają sobie zarabianie pieniędzy, dla nich organizowanie turystyki to przede wszystkim praca zarobkowa (7 z 14). 
Tab. 1. Podmioty organizujące zwiedzanie Łodzi

\begin{tabular}{|c|c|c|c|c|c|}
\hline Lp. & Nazwa grupy & Siedziba & Strona internetowa & $\begin{array}{c}\text { Promocja na } \\
\text { stronie www. } \\
\text { turystyczna. } \\
\text { lodz.pl }\end{array}$ & $\begin{array}{l}\text { Zgoda na } \\
\text { udział } \\
\text { w badaniu }\end{array}$ \\
\hline 1 & $\begin{array}{l}\text { Oddział Łódzki } \\
\text { PTTK im. Jana } \\
\text { Czeraszkiewicza }\end{array}$ & ul. Wigury 12a & www. lodz.pttk.pl & Tak & Tak \\
\hline 2 & $\begin{array}{l}\text { Przewodnicy } \\
\text { Łódzcy Totu-Totam }\end{array}$ & $\begin{array}{l}\text { ul. Piotrkowska } 17 \\
\text { lok. 69U }\end{array}$ & $\begin{array}{l}\text { www.lodz- } \\
\text { totutotam.pl }\end{array}$ & Nie & Tak \\
\hline 3 & \begin{tabular}{|l} 
Towarzystwo \\
Przyjaciół Łodzi
\end{tabular} & $\begin{array}{l}\text { ul. Piotrkowska } \\
17 / 12\end{array}$ & www.tplodzi.eu & Nie & Tak \\
\hline 4 & $\begin{array}{l}\text { Fundacja Normalne } \\
\text { Miasto Fenomen }\end{array}$ & ul. Wigury $12 a$ & $\begin{array}{c}\text { www.rowerowalodz. } \\
\text { pl } \\
\end{array}$ & Nie & Tak \\
\hline 5 & $\begin{array}{l}\text { Firma Go-to, Biuro } \\
\text { Turystyki } \\
\text { Regionalnej Piotr } \\
\text { Strzelecki } \\
\end{array}$ & ul. Senatorska 12 & www.go-to.com.pl & Tak & Tak \\
\hline 6 & $\begin{array}{l}\text { Biuro Turystyczne } \\
\text { RAFTUR }\end{array}$ & $\begin{array}{l}\text { ul. Paderewskiego } \\
33 / 16\end{array}$ & www.raftur.pl & Tak & Tak \\
\hline 7 & Visit.Łódź & brak informacji & www.visitlodz.com.pl & Nie & Nie \\
\hline 8 & Zielona Łódź & brak informacji & www.zielonalodz.info & Nie & Nie \\
\hline 9 & Central Point & ul. Narutowicza 86 & $\begin{array}{c}\text { www.centralpoint.wlo } \\
\text { dzi.com }\end{array}$ & Tak & Nie \\
\hline 10 & $\begin{array}{l}\text { Grupa Fabricum } \\
\text { Travel Services }\end{array}$ & $\begin{array}{l}\text { ul. Drewnowska } \\
58\end{array}$ & www.fabricum.pl & Tak & Nie \\
\hline 11 & Fundacja Jagiełło & brak informacji & $\begin{array}{c}\text { www.fundacjajagiello. } \\
\text { jimdo.com }\end{array}$ & Nie & Nie \\
\hline 12 & $\begin{array}{l}\text { Eódzkie Centrum } \\
\text { Wycieczek } \\
\text { Szkolnych }\end{array}$ & brak informacji & www.lcws.pl & Tak & Nie \\
\hline 13 & $\begin{array}{l}\text { Usługi Turystyczne } \\
\text { ALEX }\end{array}$ & ul. Rydla 6/39 & www.odkryj.lodz.pl & Tak & Nie \\
\hline 14 & $\begin{array}{l}\text { Towarzystwo } \\
\text { Opieki nad } \\
\text { Zabytkami w Łodzi }\end{array}$ & ul. Wigury $12 a$ & $\begin{array}{l}\text { www.tonz.org.pl/ } \\
\text { lodz }\end{array}$ & Nie & Nie \\
\hline
\end{tabular}

Źródło: opracowanie własne.

Wszystkie placówki zakwalifikowane do badania promują siebie i swoje działania za pomocą stron internetowych. Jednakże w przypadku dwu podmiotów ich strony internetowe nie są na bieżąco aktualizowane, co może stanowić pewną przeszkodę w nawiązaniu $\mathrm{z}$ nimi kontaktu. Pozostałe jednostki na bieżąco uzupełniają treści na swoich stronach. Dodatkowo, w przypadku sześciu z nich, na stronach internetowych można znaleźć kalendarium imprez na najbliższy miesiąc lub dłuższy czas. Również na stronach sześciu 


\begin{tabular}{|c|c|c|c|c|c|c|c|c|c|c|c|c|c|}
\hline 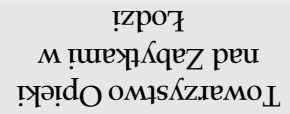 & 氙 & & Z & $\sum_{\text {出 }}$ & क & + & 1 & 1 & + & 1 & 1 & $\mathrm{~N}$ & 1 \\
\hline 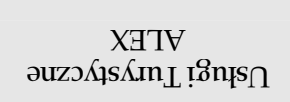 & $\Xi$ & 1 & $\checkmark$ & $\stackrel{N}{\sum}$ & $\begin{array}{l}\varphi^{2} \\
\vec{\omega}\end{array}$ & + & & & 1 & 1 & 1 & 3 & 1 \\
\hline 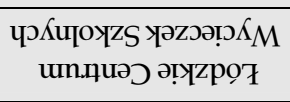 & क्ञ & 1 & 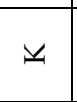 & $\stackrel{2}{\sum_{i}}$ & $\begin{array}{l}\text { pे } \\
\text { के }\end{array}$ & + & 1 & 1 & 1 & 1 & I & 3 & 1 \\
\hline оңә!ด̊е[ еџерип & $\Xi$ & 1 & Z & 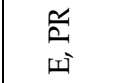 & क & 1 & 1 & 1 & 1 & 1 & I & 3 & 空方交 \\
\hline unगtiqqe & $\Xi$ & ర్ & $\checkmark$ & 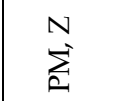 & $\begin{array}{l}\stackrel{\varphi}{\vec{\omega}} \\
\vec{\omega}\end{array}$ & + & + & 1 & 1 & + & 1 & 3 & 1 \\
\hline 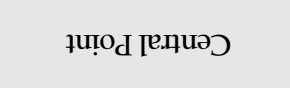 & 을 & 1 & 4 & $\sum_{i}^{N}$ & क & + & 1 & $\begin{array}{l}z \\
<\end{array}$ & + & + & + & 3 & $\stackrel{5}{3}$ \\
\hline zро7 еиорә!Z & $\sigma$ & 1 & Z & 成充交 & ๘ & + & + & 1 & 1 & 1 & 1 & $\mathrm{~N}$ & छิ ڤิ \\
\hline 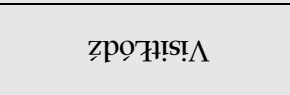 & $\infty$ & 1 & צ & $\sum_{i}^{N}$ & $\begin{array}{l}\text { क्ये } \\
\vec{\omega}\end{array}$ & 1 & 1 & $\begin{array}{l}Z \\
\text { Z }\end{array}$ & 1 & 1 & 1 & 1 & 1 \\
\hline 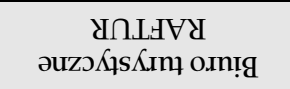 & $\Phi$ & ঃั & $\underline{v}$ & $\stackrel{N}{i}$ & क & + & + & 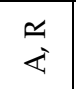 & 1 & + & 1 & 3 & 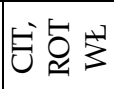 \\
\hline 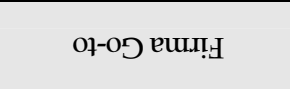 & e & & $\underline{\forall}$ & $\sum_{i}^{N}$ & क & + & 1 & $\varangle$ & 1 & 1 & । & $\mathrm{N}$ & 㧍方 \\
\hline иәшоиән е! верип & E & ڤ్సి & Z & 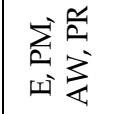 & क & + & + & 1 & 1 & 1 & 1 & $\mathrm{~N}$ & $\sum_{S}^{M}$ \\
\hline 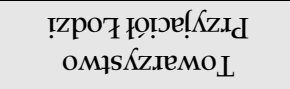 & $\Xi$ & & Z & 听公交 & क & + & + & 1 & 1 & & । & 3 & 志方 \\
\hline 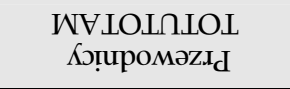 & 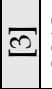 & & 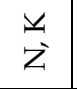 & 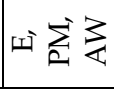 & $\begin{array}{l}\text { 至 } \\
\text { क }\end{array}$ & + & 1 & z & 1 & 1 & । & 3 & $\sum_{S}^{+}$ \\
\hline 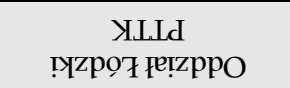 & & 1 & Z & 听恋交 & $\begin{array}{l}\text { कि } \\
\vec{\omega}\end{array}$ & + & + & 1 & + & & + & $\mathrm{N}$ & 岕 \\
\hline ध्छ & $\Xi$ & 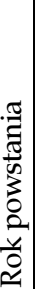 & 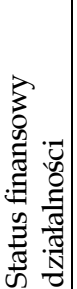 & 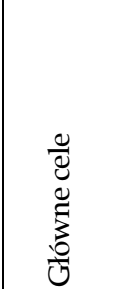 & 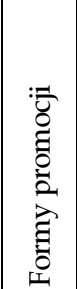 & 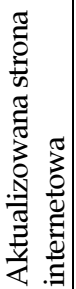 & 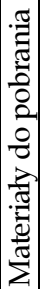 & 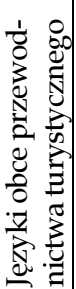 & 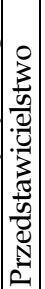 & : & $\frac{\mathrm{z}}{\mathrm{N}}$ & 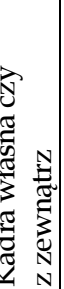 & $\begin{array}{c}\vdots \\
N \\
\widetilde{0} \\
\frac{\pi}{0} \\
\frac{0}{0} \\
\frac{0}{2} \\
3\end{array}$ \\
\hline
\end{tabular}




\begin{tabular}{|c|c|c|c|c|c|c|c|c|c|c|c|}
\hline $\mid$ & $\Sigma$ & + & 1 & 1 & 1 & + & 位 & + & 1 & 1 & 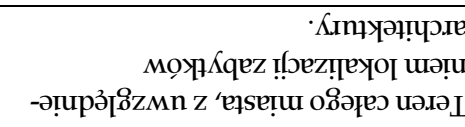 \\
\hline$\Xi$ & a & + & + & 1 & + & + & 1 & 1 & & & 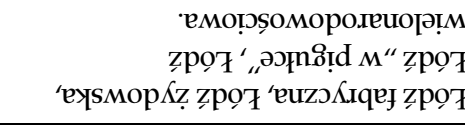 \\
\hline$\stackrel{\infty}{=}$ & a & + & + & 1 & 1 & + & 1 & 1 & 1 & 1 & 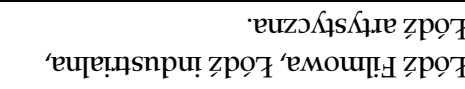 \\
\hline$\stackrel{ }{\Xi}-$ & $\Sigma$ & + & 1 & 1 & 1 & + & $\simeq$ & + & 1 & 1 & 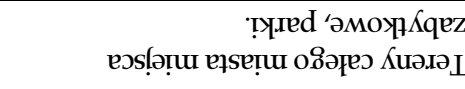 \\
\hline$\Xi$ & a & + & + & + & + & + & $\left|\begin{array}{c}0 \\
2 \\
\infty \\
0 \\
\text { si } \\
z\end{array}\right|$ & & $\left|\begin{array}{l}\tilde{0} \\
\vdots \\
+1\end{array}\right|$ & 1 & 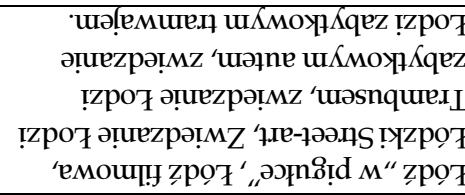 \\
\hline 의 & a & + & + & + & 1 & ++ & $\left|\begin{array}{l}\infty \\
\hat{Z}\end{array}\right|$ & & 1 & 1 & 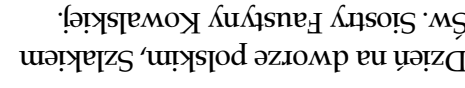 \\
\hline$\sigma$ & $\Sigma$ & + & 1 & 1 & 1 & 1 & z & + & 1 & I & 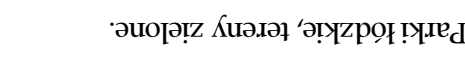 \\
\hline$\infty$ & a & + & + & 1 & 1 & 1 & $\begin{array}{l}\infty \\
\mathbf{z} \\
\end{array}$ & & 1 & 1 & 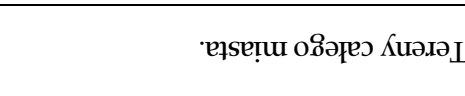 \\
\hline$\triangle$ & a & + & + & + & 1 & + & 至 & & \begin{tabular}{|l|l|}
$x$ \\
0 \\
1 \\
\end{tabular} & 1 & 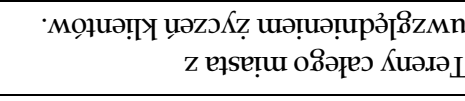 \\
\hline 0 & a & + & + & + & 1 & + & 安 & & \begin{tabular}{|c|c|} 
\\
$\substack{1 \\
m}$
\end{tabular} & $\frac{\Xi}{\infty}$ & 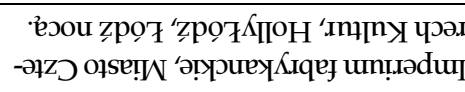 \\
\hline ()- & $\Sigma$ & + & 1 & 1 & 1 & 1 & $\simeq$ & & ल & $\frac{\tilde{g}}{\underline{n}}$ & 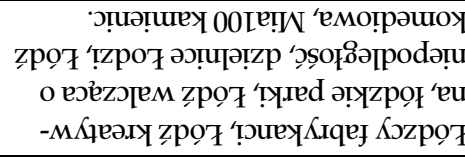 \\
\hline$\Xi$ & $\Sigma$ & + & + & 1 & 1 & + & $\begin{array}{l}\infty \\
\bar{Z} \\
\end{array}$ & + & $\exists$ & 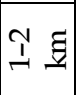 & 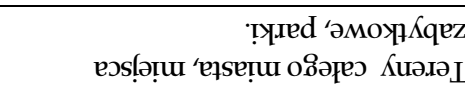 \\
\hline 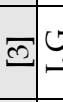 & $\sum_{\infty}$ & + & + & 1 & 1 & 1 & $|\hat{z}|$ & + & สี & $\frac{\tilde{g}}{\mathrm{~N}}$ & 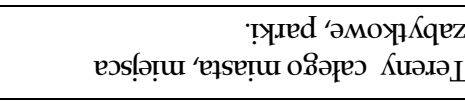 \\
\hline$\overline{\mathrm{N}}$ & $\Sigma$ & + & I & 1 & 1 & + & $\hat{z}$ & + & ल) & 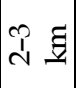 & 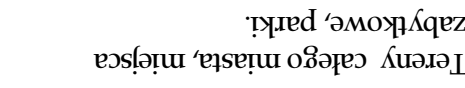 \\
\hline$\Xi$ & 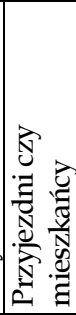 & 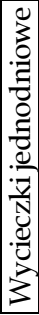 & 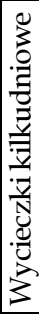 & 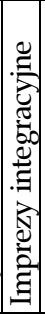 & 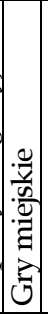 & 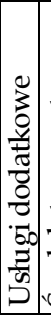 & 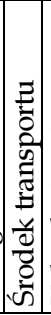 & . & 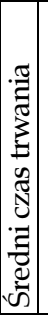 & 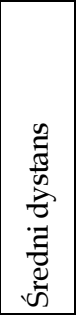 & 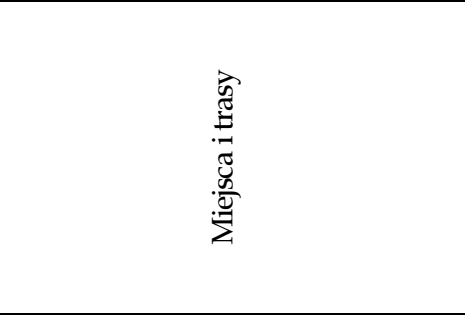 \\
\hline
\end{tabular}

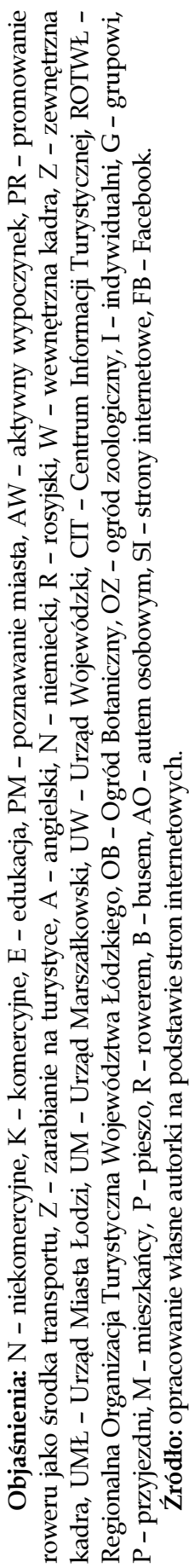


podmiotów znajdują się materiały do pobrania, z których użytkownicy mogą skorzystać, są to m.in. trasy wycieczek, regulaminy uczestnictwa, karty zgłoszeniowe. Na portalu społecznościowym Facebook można odnaleźć profile sześciu z 14 organizacji. Są one wykorzystywane do informowania o bieżących sprawach, publikowania zdjęć i nagrań z wycieczek. Na serwisie społecznościowym Instagram natomiast ma założone konto tylko jeden podmiot (Łódzkie Centrum Wycieczek Szkolnych).

Możliwość przewodnictwa w języku obcym gwarantuje pięć firm. Wszystkie proponują język angielski, dodatkowo trzy z nich oferują język niemiecki, a dwa - rosyjski. Wśród badanych jednostek znalazły się trzy będące przedstawicielstwami większych podmiotów, takich jak PTTK, Agencja Turystyczna „Wilejka” i Towarzystwo Opieki nad Zabytkami. Na stronach internetowych trzech podmiotów znajdziemy certyfikaty świadczace o wysokim poziomie oferowanych usług, wszystkie z nich prowadzą działalność komercyjną. Zniżki na uczestnictwo w proponowanych wycieczkach oferują tylko dwa podmioty - Łódzki Oddział PTTK oraz Central Point. Przewodnikami w czasie wycieczek, w przypadku ośmiu grup, są ich pracownicy wykwalifikowana kadra, która ciągle podnosi swoje umiejętności. Inne instytucje nie zatrudniają w swoich szeregach przewodników, ale w razie potrzeby zatrudniają osoby spoza firmy. Bardzo często są to ludzie, z którymi współpracują od dłuższego czasu. Większość z opisywanych organizacji (9 z 14) prowadzi współpracę z urzędami miejskimi, które współfinansują wybrane działania lub korzystają z ofert przygotowanych przez firmy (tab. 2).

Uczestników wycieczek przygotowanych przez omawiane podmioty można podzielić na indywidualnych (najczęściej są to mieszkańcy miasta) i grupowych (do których należą osoby przyjezdne). Oczywiście można także spotkać turystów indywidualnych, którzy przyjeżdżają do Łodzi i korzystają z usług przewodnika. Wśród klientów podmiotów niekomercyjnych przeważają mieszkańcy Łodzi, natomiast w przypadku firm komercyjnych w grupie uczestników dominują osoby przyjezdne. Informacje te pochodzą z wywiadów, przeprowadzonych z pracownikami placówek, które zgodziły się na udział w badaniu.

Forma organizacyjna poznawania miasta zależy w dużej mierze od dystansu, który trzeba pokonać. Spośród 14 podmiotów, 10 zaprasza na piesze spacery, które ograniczają się do niedużego obszaru położonego w obrębie granic Łodzi. Aktywność rowerową związaną z pokonywaniem większego dystansu proponują dwie jednostki (Fundacja Fenomen i Fundacja Jagiełł), możliwość skorzystania z busa zakładają cztery z 14 firm, a zwiedzanie 
miasta samochodem oferuje tylko Grupa Fabricum. Wszystkie instytucje poddane analizie organizują wycieczki jednodniowe, tzw. spacery. Najczęściej trasa takiego przejścia wynosi do $3 \mathrm{~km}$, a czas potrzebny na jego pokonanie sięga około 3 godzin, wraz z komentarzem przewodnika i jego odpowiedziami na zadawane pytania. W przypadku podróży rowerowych dystans zwiększa się np. do $15 \mathrm{~km}$, ale czas trwania również zamyka się w 3 godzinach.

$\mathrm{Na}$ stronach internetowych dziewięciu jednostek można znaleźć informacje o organizowaniu ofert kilkudniowych. Przygotowują je podmioty komercyjne, które utrzymują się z działalności turystycznej. Możliwość zorganizowania imprez integracyjnych proponują cztery instytucje, a dwie przygotują dla uczestników gry miejskie (Grupa Fabricum oraz Usługi Turystyczne Alex). Zdecydowana większość opisywanych podmiotów (10 z 14) proponuje usługi dodatkowe osobom korzystającym z ich działalności (najczęściej możliwość zakupu pewnych publikacji, pomoc w rezerwacji hotelu, środka transportu, biletu do teatru).

Trasy niektórych wycieczek, spacerów lub odwiedzane miejsca często się powtarzają. Szczególnym zainteresowaniem turystów i odwiedzających cieszą się obiekty zabytkowe, np. pałace i wille fabrykantów, fabryki, muzea, miejsca związane z "Łodzią filmową", „bajkową". Dużą popularnością wyróżniają się także tereny zielone, np. parki. W ofertach często pojawia się Szlak Łódzkich Murali.

Podsumowując, zdecydowana większość proponowanych rodzajów aktywności turystycznej jest realizowana w centrum miasta, gdzie znajduje się najwięcej atrakcji. Czasami grupy organizujące zwiedzanie Łodzi decydują się na pokazanie terenów poza centrum, jest to jednak zdecydowanie mniejsza część przygotowanych ofert.

\section{Rola grup jako popularyzatorów turystyki i rekreacji w mieście}

Wszystkie z zaprezentowanych grup chcą przekazać w swoich działaniach turystom i rekreantom autentyczność Łodzi. Autentyczność, która jest pojmowana jako rzeczywisty, oryginalny, unikatowy i wyjątkowy charakter miejsca, stała się jedną z cech wyróżniających współczesną turystykę (KULCZYK 2013). 
Zdecydowana większość opisanych powyżej grup jako najbardziej rozpowszechniony rodzaj działalności turystycznej i rekreacyjnej w czasie swoich działań wykorzystuje aktywność pieszą, która łączy w sobie wysiłek fizyczny oraz doznania estetyczne. Dodatkowo część propaguje turystykę rowerową.

Zdaniem reprezentantów grup instytucji organizujących zwiedzanie miasta i okolic, udział $\mathrm{w}$ tych rodzajach aktywności jest doskonałą formą wypoczynku, która poza relaksem i regeneracją sił dodatkowo wyrabia nawyk pożytecznego spędzania czasu wolnego. Poza tym nie sposób nie wspomnieć o tym, że takie spotkania pozwalają rozwijać zainteresowania, dają szansę na pogłębiony rozwój intelektualny. Wszystkie grupy pisząc o swoich celach zwracają szczególną uwagę na wymiar edukacyjny swojej działalności.

Przygotowując pomysły na wycieczki czy trasy spacerów, ludzie zaangażowani w taką działalność próbują zaprezentować uczestnikom tożsamość miasta i okolicy. Chcą, aby więcej osób poznało od dobrej strony miejsce swojego zamieszkania. Oczywiście $\mathrm{z}$ racji nieprzymuszanego uczestnictwa $\mathrm{z}$ takiej oferty korzystają osoby, które faktycznie chcą poznać swoje miasto. Daje to ogromną szansę na odkrywanie i poznawanie ciekawostek, które pomagają zapamiętać i utrwalić zdobytą w czasie wycieczek wiedzę.

Głównym kryterium zachowania i podtrzymania tożsamości danego miejsca jest jej przekaz jak najszerszemu gronu ludzi. Tożsamość czy też dziedzictwo miasta określa m.in. historię danego miejsca, jego tradycje, język (gwara) i folklor. Jednym $\mathrm{z}$ najprostszych sposobów na przekazanie dziedzictwa danego miejsca jest jego poznanie. Grupy biorące udział w badaniu, w swojej działalności realizują ten cel. W miejscach, do których zapraszają, uczestnicy mogą poznać różne fragmenty dawnej Łodzi, m.in. pomniki, muzea, miejsca, w których mieszkali lub pracowali wybitni ludzie, budowniczowie miasta. Dobór takich miejsc powinien służyć kształtowaniu więzi emocjonalnych z miastem oraz wyrobieniu pozytywnej opinii o miejscu swojego zamieszkania. Osoby biorące udział w badaniu podkreślały, że chciałyby aby $\mathrm{w}$ przyszłości $\mathrm{w}$ świadomości łodzian funkcjonował pozytywny obraz miasta.

Ważnym aspektem działania grup popularyzujących turystykę i rekreację $\mathrm{w}$ Łodzi jest to, że pozwalają przezwyciężać podziały społeczne i podziały pokoleniowe. $W$ trakcie wycieczek, czy spacerów spotykają się różni ludzie, $\mathrm{w}$ różnym wieku. Daje to szansę na rozmowę, poznanie, przezwyciężanie uprzedzeń. 


\section{Wnioski}

Grupy reprezentujące instytucje organizujące zwiedzanie Łodzi, biorące udział w badaniu, proponują różne formy zwiedzania miasta i okolic - wycieczki piesze, rowerowe, autokarowe. Prowadzona przez podmioty niekomercyjne działalność turystyczno-rekreacyjna służy przede wszystkim takim celom, jak: poszerzenie wiedzy, rozwijanie zainteresowań, poznanie piękna "małej ojczyzny" oraz nawiązanie więzi z własnym miastem, odkrycie i zrozumienie jego odmienności oraz kształtowanie nawyków aktywnego spędzania czasu wolnego. Podmioty prowadzące działalność komercyjną również pragną przekazać wiedzę dotyczącą miasta oraz rozbudzić pozytywne zainteresowanie Łodzią, jednak największą uwagę skupiają na działalności zarobkowej. Instytucje będące podmiotem zainteresowania $\mathrm{w}$ niniejszym opracowaniu promują się przede wszystkim na stronach internetowych, choć nie wszystkie podmioty aktualizują swoje strony na bieżąco. Tylko sześć organizacji zamieściło na nich materiały do pobrania (kalendarz wydarzeń, trasa zwiedzania). Możliwość zwiedzania miasta w języku angielskim zapewnia pięć organizacji, język niemiecki - trzy, a rosyjski - dwie. Część placówek prowadzi stałą współpracę z urzędami i firmami w Łodzi. Analizując miejsca i trasy proponowane przez podmioty okazuje się, że większość $\mathrm{z}$ nich zaprasza do obiektów zabytkowych zlokalizowanych w całym mieście oraz łódzkich parków. Natomiast sześć z nich proponuje zwiedzanie szlakami tematycznymi związanymi z największymi atrakcjami, dziedzictwem filmowym, fabrykanckim czy śladami wielokulturowości dawnej Łodzi.

\section{Bibliografia}

Krajoznawstwo i turystyka w szkole. Poradnik, 2003, Zarząd Główny PTTK, Warszawa.

KRUCZEK Z., SACHA S., 2001, Geografia atrakcji turystycznych Polski, Wyd. Proksenia, Kraków.

KULCZYK S., 2013, Krajobraz i turystyka. O wzajemnych relacjach, Wyd. UW, Warszawa.

LISZEWSKI S., 2006, Nowe przestrzenie turystyczne i rekreacyjne w Polsce $i$ ich rola w rozwoju kraju i regionu, [w:] G. Gołembski (red.), Turystyka w ujęciu podmiotowym i przestrzennym. Człowiek - Przestrzeń - Przedsiębiorstwo, Wyd. Akademii Ekonomicznej w Poznaniu, Poznań, s. 113-125.

LUBOWIECKI-VIKUK A.P., 2008, Stan i perspektywy rozwoju rekreacji i turystyki w Koninie, [w:] M. Lisowski (red.), Turystyka i rekreacja w mieście, Wyd. Wyższa Szkoła Menadżerska w Białymstoku, Białystok, s. 121-126.

MATCZAK A., 2008, Turystyka miejska - kierunki badań geograficznych, [w:] Turystyka miejska, Wyd. Uczelniane WSG, Bydgoszcz, s. 17-24.

MIKA M., 2014, Założenia i determinanty podtrzymywalności lokalnego rozwoju turystyki, Wyd. UJ, Kraków. 
PAWLICZ A., 2008, Promocja produktu turystycznego. Turystyka miejska, Wyd. Difin, Warszawa.

WOJALSKI M. Z., 2000, Kieszonkowa Kronika Dziejów Łodzi, Widzewska Oficyna Wydawnicza ZORA, Łódź.

WYZUJ M, 2008, Turystyka w wojewódzkich miastach Polski, [w:] M. Lisowski (red.), Turystyka i rekreacja w mieście, Wyd. Wyższa Szkoła Menadżerska w Białymstoku, Białystok, s. 21-30.

http:/ / lodz.naszemiasto.pl/artykul/lodz-sie-wyludnia-to-rekord-w-skali-kraju,3374722,art,t,idtm. html; 28.02.2016.

http:/ / www.centralpoint.wlodzi.com/; 28.02.2016.

http:/ / www.fabricum.pl/; 28.02.2016.

http://www.fundacjajagiello.jimdo.com/; 25.02.2016.

http://www.go-to.com.pl/; 28.02.2016.

http:/ / www.lcws.pl/; 25.02.2016.

http:/ / www.lodz.pttk.pl/; 25.02.2016.

http:/ / www.lodz-totutotam.pl/; 28.02.2016.

http:/ / www.odkryj.lodz.pl/; 28.02.2016.

http:/ / www.raftur.pl/; 28.02.2016.

http://www.rowerowalodz.pl/; 27.02.2016.

http://www.tplodzi.eu/; 27.02.2016.

http://www.turystyczna.lodz.pl/; 28.02.2016.

http://www.visitlodz.com.pl; 27.02.2016.

http:/ / www.zielonalodz.info; 22.02.2016. 